\title{
HISTOPATHOLOGIC FINDINGS OF PULMONARY ACARIASIS IN A RHESUS MONKEYS BREEDING UNIT
}

\author{
MÁRCIA CRISTINA R. ANDRADE ${ }^{1}$; RENATO S. MARCHEVSKY ${ }^{2}$
}

\begin{abstract}
ANDRADE, M.C.R.; MARCHEVSKY, R.S. Histopathologic findings of pulmonary acariasis in a rhesus monkeys breeding unit. [Aspectos histopatológicos da acaríase pulmonar em uma criação de macacos rhesus.] Revista Brasileira de Parasitologia Veterinária, v. 16, n. 4, p. 229-234, 2007. Departamento de Primatologia, Centro de Criação de Animais de Laboratório, Fundação Oswaldo Cruz, Av. Brasil, 4365, Manguinhos, RJ 21040-900, Brazil. E-mail: andrade@fiocruz.br

Histological lesions in the lungs of rhesus monkeys (Macaca mulatta) related with Pneumonyssus simicola were evidenced. The most prominent pathologic alterations included numerous thin-walled cysts $1-5 \mathrm{~mm}$ diameter scattered throughout the lungs, bronchiolitis, peribronchiolitis where the mites were found associated with pigmented and non-pigmented materials. Our study included data from 347 rhesus monkeys submitted to necropsies during 20 years. Four adult debilitated animals were found with pulmonary acariasis which showed a very low incidence of parasite $(1.2 \%)$ in the colony. Most of the published literature described as common and widespread pulmonary acariasis in Old World monkeys. The present study confirms the ubiquity of $P$. simicola in captive born and raised rhesus monkeys that would compromise experimental studies involving the respiratory system.
\end{abstract}

KEY WORDS: Rhesus macaques, pulmonary acariasis, Pneumonyssus simicola, pathology.

\section{RESUMO}

Foram evidenciadas lesões histológicas nos pulmões de macacos rhesus (Macaca mulatta) relacionadas ao Pneumonyssus simicola. As principais alterações incluíram numerosos cistos variando de 1-5 $\mathrm{mm}$ de diâmetro, com paredes finas e amplamente distribuídos nos pulmões; bronquiolite e peribronquiolite, onde os ácaros foram encontrados associados com materiais particulados pigmentados ou não. Nosso estudo incluiu dados de 347 macacos rhesus submetidos a necropsias no decorrer de 20 anos. A acaríase pulmonar foi diagnosticada em quatro animais adultos debilitados, o que representou uma incidência muito baixa do parasita $(1,2 \%)$ na colônia. A literatura descreve uma alta incidência de acaríase pulmonar em macacos do Velho Mundo. O presente estudo confirma a ubiqüidade do $P$. simicola em macacos rhesus nascidos e manejados em cativeiro, que compromete sua utilização em estudos experimentais envolvendo o sistema respiratório.

${ }^{1}$ Departamento de Primatologia, Centro de Criação de Animais de Laboratório, Fundação Oswaldo Cruz, Av. Brasil, 4365, Manguinhos, RJ, 21040-900 Brazil. E-mail: andrade@fiocruz.br

${ }^{2}$ Laboratório de Neurovirulência, Bio-Manguinhos, Fundação Oswaldo Cruz.
PALAVRAS-CHAVE: Macacos rhesus, acaríase pulmonar, Pneumonyssus simicola, patologia.

\section{INTRODUCTION}

Pulmonary acariasis (Pneumonyssus simicola) is one of the most frequent parasites in non-human Old World primates and often found in rhesus monkeys (Macaca mulatta) (FURMAN et al., 1974; LEATHERS, 1978; HIRAOKA et al., 2001). There are several species of Pneumonyssus that infest many animals (FURMAN, 1954).

Macroscopically there are multiple cystic lesions up to several millimeters or air-filled bullae often in the hilar region of lung lobes toward the dorsal aspects. These cases showed no other abnormal gross finding (FURMAN et al., 1974; HIRAOKA et al., 2001; KIM; KIM, 2003).

The histopathologic evaluation included the following findings: multifocal granulomatous lesions on the terminal air passages consisting of a large number of eosinophils, epithelioid cells, foreign body type giant cells, and collagen fibers were aggregated around pigmental bodies. At least three distinctive pigmented and non-pigmented materials are identified in association with lung mite infection. Most of pigmental bodies is composed of siliceous materials (KIM; KIM, 2003). The other types were formed by products of mucin 
substances, hemosiderin and/or lipofuscin (BRACK, 1972). They are multiple and play an important role in perpetuating lung lesions, even though live mites no longer reside within the lungs (JOSEPH et al., 1984).

The prevalence of pulmonary acariais in wild-caught rhesus monkeys maintained in the laboratory approaches $100 \%$ (FAIRBROTHER; HURST, 1932; INNES et al., 1954; HIRAOKA et al., 2001) and has received the greatest attention with reference to lung mites by virtue of widespread use of these primates as experimental laboratory animals, particularly for medical research (FURMAN et al., 1974).

Nearly all imported rhesus monkeys have P. simicola infections (RAWLINGS; SPLITTER, 1973). The close physical association with imported adult animals seems required at least for the initial infestation. Four of 16 captivebred rhesus monkeys (25\%) raised in the company of imported adults for up to 16 years were found at autopsy to be parasitized with lung mites (KNEZEVICH; MCNULTY, 1970). In contrast, monkeys born and raised in laboratories have low incidence of infection (RAWLINGS; SPLITTER, 1973).

The presence of lung mites in Old World monkeys is an important consideration in research. Certain investigators feel that the presence of lung mites compromises the use of imported rhesus monkeys in pulmonary studies (RAWLINGS; SPLITTER, 1973). On the other hand, this parasitic disease has been used as a model for asthma (ISHIZAKA et al., 1969), asbestosis, silicosis and other pneumoconioses (KIM, 1988).

Pneumonyssus simicola is a member of the family Halarachnidae, measuring approximately 300 to $500 \mu \mathrm{m}$ in diameter. Mites are obligatory endoparasitic organisms living in the respiratory tracts and feed on host pulmonary epithelial cells, erythrocytes and lymph (FURMAN, 1977).

Since parasitic members of the order Acari, to which Pneumonyssus belongs (FURMAN, 1954), do not require intermediate vectors (FURMAN, 1954; KIM, 1974), it has been proposed that cross-infection may occur through the feces, during grooming, or by inhalation of respiratory aerosol. Tracheal washes yield primarily larva, supporting the theory that larvae migrate to the pharynx and larynx where they are transmitted to other monkeys by direct contact, or in heavy infections through coughing and sneezing (POVAR, 1965).

Pulmonary acariasis is not transmissible to humans (zoonotic), considered of little clinical importance until certain aggravating factors in case of viral or bacterial pneumonia, many times leading to high morbidity and mortality (INNES et al., 1954). Pneumatoceles or bullae have been reported in infant animals with suppurative complication. This probably occurs from parasitic infection with superimposed bacteria infection. The great majority of the cases were caused by Staphylococcus aureus infection which causes acute and necrotizing pneumonia (GILLETT et al., 1984).

Although the parasite usually does not determine clinical manifestations, the animals could also present serious infections characterized by cough and dyspnea and in severe cases, it may cause death. However, most lung lesions were discovered as incidental lesions in monkeys that died of pneumonia or diarrhea and/or enteritis (HIRAOKA et al., 2001). The most serious complications resulting in mortality are pneumonia, pneumothorax or pulmonary arteritis culminating in a picture of hemothorax (WOODARD, 1968).

There is strong evidence that air transmission of the $P$. simicola can occur which represents a compromise between keeping primates in large groups. However, as transmission requires intimate contact with the infected animals (JOSEPH et al., 1984), it can be avoided by separating the offspring from the mothers immediately after birth (KNEZEVICH; MCNULTY, 1970). Cesarean-derived monkeys have been maintained free from pulmonary acariasis (RAWLINGS; SPLITTER, 1973). Knezevich and Mcnulty (1970) stated that mite-free monkeys can be raised without difficulty may have been overly optimistic.

It should be distinguished from that of other granulomatous diseases including those caused by a strange body and by certain microorganisms (HIRAOKA et al., 2001). According to Gillett et al. (1984) advanced mycobacteriosis may cause cavitations within caseated lung tubercules, but these are characterized as thick-walled irregular air pockets within densely consolidated parenchyma. Infectious pneumonia and lung mite infestation should be considered when pulmonary air-filled lesions are observed radiographically in nonhuman primates.

Large air filled pulmonary lesions can vary from thick, irregular walled cavitations seen with tumors and abscesses to thin smooth walled pneumatoceles that are rapidly changing lesions created by replacement of necrotic tissue with air (GILLETT et al., 1984).

The concept of therapy for the control or elimination of lung mite infestations has received attention (FURMAN et al., 1974). Ivermectin $(200 \mu \mathrm{g} / \mathrm{kg})$ appears effective for the elimination of Pneumonyssus sp. infection in non-human primates (JOSEPH et al., 1984). Chemotherapy with an organic phosphate has shown promise in reducing the number of active mite lesions; long-term prophylaxis in a breeding colony may eradicate the parasite (KNEZEVICH; MCNULTY, 1970). Infected animals should be isolated from other non-human primates to prevent transfer of lung mite larvae by coughing (KIM, 1988). Histopathologically, inflammatory changes progressively decreased with increasing time post treatment (JOSEPH et al., 1984).

This study is a survey of the presence of Pneumonyssus simicola in a closed colony of rhesus monkeys destined for biomedical research.

\section{MATERIAL AND METHODS}

\section{Object of the study}

The studied animals belong to the Departamento de Primatologia do Centro de Criação de Animais de Laboratório da Fundação Oswaldo Cruz, Rio de Janeiro. The current breeding colony houses about 450 rhesus monkeys that have been used extensively in animal model development, virology, viral 
pathogenesis, vaccine development and testing, pharmacodynamic models, preclinical safety, and efficacy studies.

\section{Animal handling}

The animals are bred in a group system (polygamic system). Twenty to twenty-five animals are housed in cages measuring 48 $\mathrm{m}^{2}$, with one reproducer male for 8-10 reproducer females and their offspring. The diet consists of dry commercial diets in the morning, fruits and vegetables in the afternoon and water ad libitum. The cages are cleaned daily with a high pressure washer.

\section{Medical management}

The entire colony is checked daily by a team of veterinarians for any sign of clinical abnormalities. Once a year the animals are anaesthetized with ketamine hydrochloride (Vetarnacol ${ }^{\circledR}$ : König, Argentina) $(10 \mathrm{mg} / \mathrm{kg}$ ) and submitted to a clinical examination for establishing their health status and for collection of fecal and blood samples for routine laboratory testing. These examinations also include tuberculin skin test, haematological and serum biochemical values as well as subcutaneous administration of ivermectin $(200 \mu \mathrm{g} / \mathrm{kg})$ as previously described (ANDRADE et al., 2004).
The breeding colony is cleared by the Ethics Commission for the Use of Animals of Fiocruz (authorization number P004200 ) and follows the regulations for the use of laboratory animals of the Guide for the Care and Use of Laboratory Animals (1996).

\section{Necropsy and histological examination}

Animals which unexpectedly die are submitted to full necropsy for conclusion of the clinical diagnosis and epidemiological study. During the 20 year period (1983-2003), 347 necropsies were performed.

Lung samples were obtained and immediately fixed in 10\% neutral buffered formalin. After dehydration and routine paraffin-embedding $4 \mu \mathrm{m}$ sections were made and routinely stained with hematoxylin and eosin, Masson trichrome, Perls Prussian blue (for iron), periodic acid Schiff (mucin substances), and Von Kossa (for calcium), which were examined by light microscopy.

\section{RESULTS}

The pulmonary lesions occurred in 4 adult debilitated animals, one female and three males, corresponding to a frequency of $1.2 \%$ of the parasite in the studied colony.

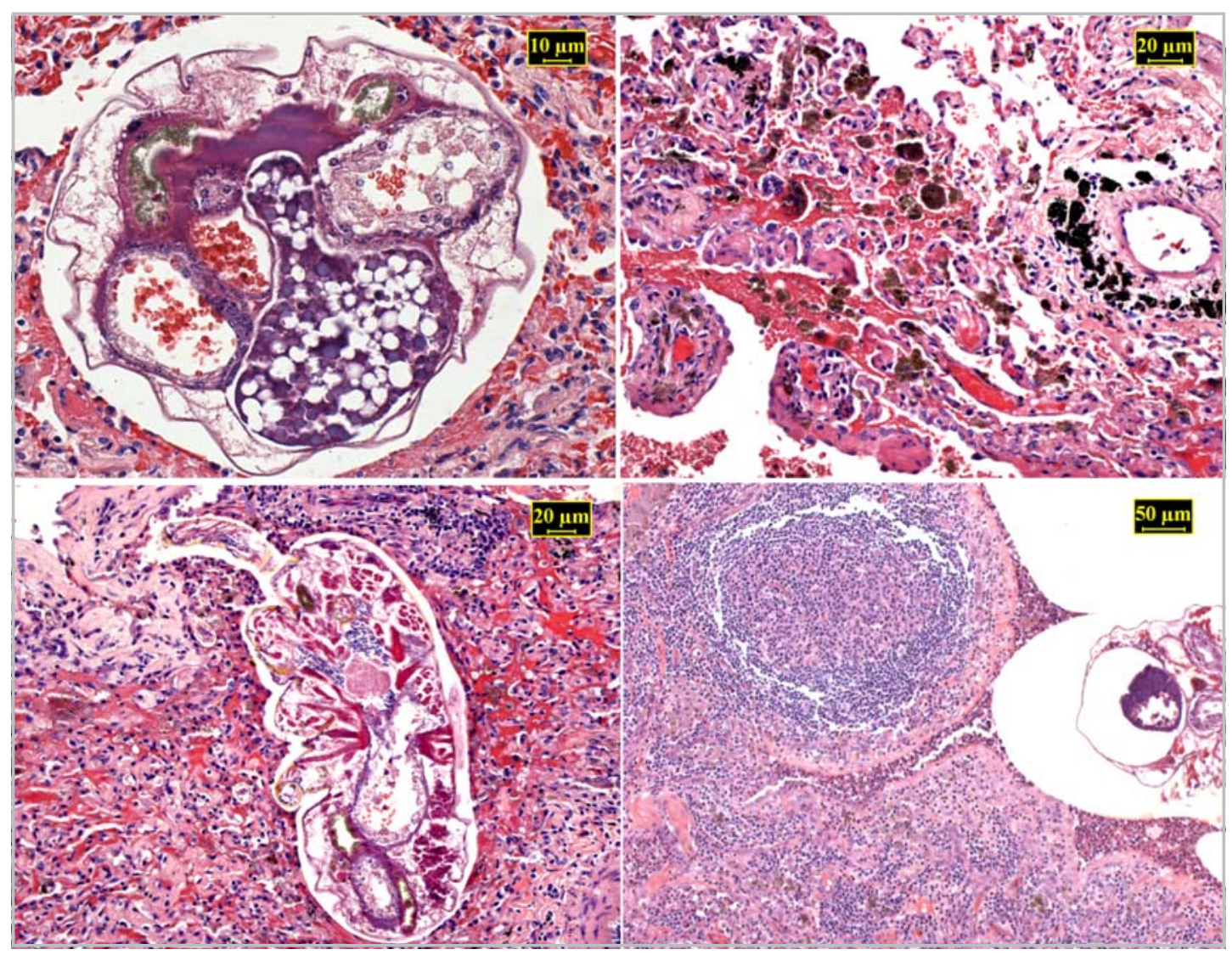

Figure1. Histopathologic features of lung tissue from rhesus monkey caused by Pneumonyssus simicola. Hematoxylin-eosin (H\&E)-stained paraffin section. A: single mite characterized by exoskeleton and chitinous appendages, striated muscle, gut segments and uterus with yolk material. B: hypercellularity of alveolar walls, alveolar spaces containing yellow-brown pigmented-laden macrophages peculiar in $P$. simicola infection. Antrachotic pigment (black) was most prominent in the adventitia of medium-size vessels. C: mite in the bronchial lumen. Thickening of the bronchial wall due to inflammatory granulomatous process.D: $P$. simicola in the bronchial wall showing hypercellarity represented by submucosal and interstitial inflammation with granulocytes (neutrophils and eosinophils), plasma cells and mononuclear cells. 
Grossly, monkeys showed multifocal thin-walled cysts 1$5 \mathrm{~mm}$ diameter, scattered throughout the lungs lobes. Usually these cysts have a yellowish wall and contain serous fluid or inspissated secretions. There was marked reticulated anthracosis of the pleural surfaces.

Microscopically (Figure 1), the main changes involved the bronchi or bronchioles with inflammatory, degenerative, and necrotic features where adults and larvae mites were present. $P$. simicola were basically characterized by exoskeleton and chitinous appendages, striated muscle, gut segments and uterus with yolk material. Peribronchiolitis presented as a surrounding heavy infiltration, was made up of lymphocytes, neutrophils, eosinophils, and macrophages. In addition to these findings, pigmented materials were seen in the peribronchiolar areas of inflammation and within the alveolar macrophages.

Histochemical test for haemosiderin was moderately positive. Dark areas of anthracosis were also proeminent. The cytoplasm of some macrophages was weakly positive (products of mucin substances) to periodic acid-Schiff stain (PAS). The most abundant of the pigments found in the sections did not stain for iron, calcium and mucin substances. In some cases, the inflammatory process exhibited granuloma formation centered on the terminal air passages, accompanied by the presence of granulocytes (neutrophils and eosinophils) and plasma cells.

\section{DISCUSSION}

Infection with the lung mite P.simicola was recognized by Banks as early as 1901. Pulmonary acariasis is very common in macaques, and the prevalence coexisting with nearly $100 \%$ in newly imported and in laboratory-maintained animals. Despite this great ubiquity and morbidity few papers have been published concerning pulmonary acariasis after Banks report. Our findings confirm the ubiquity of $P$. simicola in rhesus monkeys. On the contrary to what is found in the literature, the occurrence of pulmonary acariasis seems relevant only to a small portion of the population in the present casuistic.

Transmission of $P$. simicola is presumed to occur via direct physical contact between the infected adults and infants during at least 6 months. Reloading infants after weaning may simply reduce the morbidity to zero in the course of a few generations (KNEZEVICH; MCNULTY, 1970; FURMAN et al., 1974). However, we believe that separating the offspring from their mothers and from the social group, although being an efficient method of controlling or eradicating the parasite, would lead to behavioral disorders.

Clinical signs include coughing and sneezing. Reported complications include pneumothorax and pulmonary arteritis and have led to cases of death. Radiographically, identifiable air-filled lesions seldom have been reported in nonhuman primates (BREZNOCK et al., 1975; SILVERMAN et al., 1976). Lack of clinical symptoms related to the incidental lesions was common in our study. Radiographs are of little use in diagnosis. Most lung lesions attributed to P. simicola were discovered as incidental findings at necropsy.

Many of the immunological methods and tests were not standardized in determining the presence of mite infections (GILLETT et al., 1984). Routine hematology and serum biochemistry are not useful for diagnosing lung mite infection, the blood cell count showed leukocytosis with eosinophilia that was also seen in hypersensitivity or other parasitic infections (KIM, 1988). Blood tests performed in the course of the clinical examination were not sufficiently elucidating for suspecting of any parasitic infection characteristic for $P$. simicola in the four affected animals.

None of the animals submitted to clinical examination showed positive reaction to the tuberculin skin test contrary to the hypothesized Woodward correlation (1968).

The research and development activities at Fiocruz did not include studies directly involving critical evaluations of cardiovascular-pulmonary system, but we recommend that diagnosis of $P$. simicola be included in the protocols prior to experiment. Furman et al. (1974) alert to unreliable experimental data by using animals that have lung mites. The same way, Joseph et al. (1984) emphasize the fact that the disease confounds interpretation of cardiopulmonary experiments done with affected animals.

Ivermectin appeared to be effective for the elimination of pulmonary acariasis in treated animals (JOSEPH et al., 1984). It is possible that the yearly administration of ivermectin should help to control the spread of the disease.

Observation of non-viable mites on dissection/agitation correlated well with histological evidence of mite deaths. Nearly all mites appeared live, grossly and histologically, in untreated infected monkeys while dead mites predominated in ivermectin treated animals (JOSEPH et al., 1984). The present study demonstrated that the histology also showed wellpreserved characteristics of $P$. simicola specimens: body cavity, striated musculature and joint chitinous appendages, gut segments and uterus with yolk material.

Grossly, scattered grey air-filled cysts from 1-5 mm diameter were seen throughout the lungs lobes suspicious of acariasis. Yellow or grey air-filled cysts from 1-10 mm in diameter that typically contain a mucopurulent material were consistent with partial bronchiolar obstruction due to mite inflammatory response. Mite pigments may cause a black coloration of the lesions and hilar lymph nodes.

Multifocal pyogranulomatous bronchiolitis, peribronchiolitis and pneumonitis due to response to mites were seen in all animals. Peribronchiolitis presented as a surrounding heavy infiltration, was made up of lymphocytes, neutrophils, macrophages and eosinophils. In addition to these hallmarks, pigmented materials were seen in the peribronchiolar areas of inflammation and within the alveolar macrophages. The pigment, both free and within macrophages, is golden brown. A panel of histochemical employed to elucidate nature of pigmented materials showed that haemosiderin was moderately positive, the cytoplasm of some 
macrophages was weakly positive to periodic acid-Schiff stain (PAS) and calcium precipitates were present well as a considerable proportion of the pigment granules remained unstained. The lungs also showed anthracosis due to urban air pollution.

At least three distinctive pigmental bodies are identified in association with lung mite infection. Examination of these pigmental bodies, using a high-voltage $(1.2 \mathrm{meV})$ electron microscope and an energy-dispersive X-ray analysis system, indicated that two major components of pigments contained a high concentration of silica (KIM; COLE, 1987).

Arteritis associated with infection by the lung mite, $P$. simicola, was described in rhesus monkeys. The lesions were characterized by medial hyperplasia of the vessel and adhesion of eosinophils to the intima. Mite pigment was found within the vessel wall and resulted in vascular sclerosis and the formation of a fibrous plaque. Half of 32 rhesus monkeys with lung mite lesions at necropsy also had muscular hyperplasia and hypertrophy of the pulmonary arterial vasculature (FREMMING et al., 1957). These changes were not seen in pulmonary arteries of the four studied animals.

This study alerts colleagues to the need for considering the possible presence of the lung mite especially in animals used in experimental procedures. Besides, it demonstrated the ubiquity of $P$. simicola in rhesus monkeys bred in captivity and maintained in the Fiocruz Primate Center and offers prompts re-evaluation in understanding the severity of lesions and morbidity.

\section{REFERENCES}

ANDRADE, M.C.R.; RIBEIRO, C.T.R.; SILVA, V.F.; MOLINARO, E.M.; GONÇALVES, M.A.B.; MARQUES, M.A.P.; CABELLO, P.H.; LEITE, J.P.G. Biologic data of Macaca mulatta, Macaca fascicularis, and Saimiri sciureus used for research at the Fiocruz Primate Center. Memórias do Instituto Oswaldo Cruz, v. 99, n. 6, p. 581589, 2004.

BANKS, N. A new genus of endoparasitic acarians. Geneesk Tijdschr Ned-Indie, v. 41, p. 334 - 336, 1901.

BRACK, M. Histochemistry of the lung mite pigment in infections of Pneumonyssus sp. in non-human primates. Parasitology, v. 64, n. 1, p. 47-52, 1972.

BREZNOCK, A.W.; HENRICKSON, R.V.; SILVERMAN, S.; SCHWARTZ, L.W. Coccidiodomycosis in a rhesus monkey. Journal of the American Veterinary Medical Association, v. 167, n. 7, p. 657-661, 1975.

FAIRBROTHER, R.W.; HURST, E.W. Spontaneous diseases observed in 600 monkeys. Journal of Pathology and Bacteriology, v. 35, p. 867-873, 1932.

FREMMING, B.D.; HARRIS, M.D.; YOUNG, R.J.; BENSON, R.E. Preliminary investigation into the life cycle of the monkeys lung mite (Pneumonyssus foxi). American Journal of Veterinary Research, v. 18, n. 67, p. 427-428, 1957.
FURMAN, D.P.A. A revision of the genus Pneumonyssus simicola (Acarina: Halarachnidae). Journal of Parasitology, v. 40, n. 1, p. 31-42, 1954.

FURMAN, D.P.; BONASCH, H.; SPRINGSTEEN, D.S.; RAHLMANN, D.F. Studies on the biology of the lung mite, Pneumonyssus simicola banks (Acarina: Halarachnidae) and diagnosis of infestation in macaques. Laboratory Animal Science, v. 24, n. 4, p. 622-629, 1974.

FURMAN, D.P. Observations on the ontogeny of Halarachnid mites (Acarina: Halarachnidae). Journal of Parasitology, v. 63, n. 4, p. 748-755, 1977.

GILLETT, C.S.; RINGLER, D.H.; POND, C.L. Pneumatocele in a pig-tailed macaque (Macaca nemestrina). Laboratory Animal Science, v. 34, n. 1, p. 91-93, 1984.

GUIDE FOR THE CARE AND USE OF LABORATORY ANIMALS. Washington: National Research Council, National Academic Press. 1996. 125p.

HIRAOKA, E.; SATO, T.; SHIRAI, W.; KIMURA, J.; NOGAMI, S.; ITOU, M.; SHIMIZU, K. A case of pulmonary acariasis in lung of japanese macaque. Journal of Veterinary Medical Science, v. 63, n. 1, p. 87-89, 2001.

INNES, J.R.M.; COLTON, M.W.; YEVICH, P.P.; SMITH, C.L. Pulmonary acariasis as an enzootic disease caused by Pneumonyssus simicola in imported monkeys. American Journal of Pathology, v. 30, n. 4, p. 813-835, 1954.

ISHIZAKA, K.; ISHIZAKA, T.; TADA, T. Immunoglobulin $\mathrm{E}$ in the monkey. Journal of Immunology, v. 103, n. 3, p. 445-453, 1969.

JOSEPH, B.E.; WILSON, D.W.; HENRICKSON, R.V.; ROBINSON, P.T.; BENIRSCHKE, K. Treatment of pulmonary acariasis in rhesus macaques with ivermectin. Laboratory Animal Science, v. 34, n. 4, p. 360-364, 1984.

KIM, J.C.S. Distribution and life cycle stages of Pneumonyssus sp. in old world monkeys. Journal of Medical Primatology, v. 4, n. 3, p. 70-82, 1974.

KIM, J.C.S.; COLE, R. Ultrastructural and microprobe analysis of simian lung mite pigments. American Journal of Veterinary Research, v. 48, n. 3, p. 511-514, 1987.

KIM, J.C.S. Diagnostic exercise: macaque with dyspnea. Laboratory Animal Science, v. 38, n. 1, p. 77-78, 1988.

KIM, J.C.S.; KIM, M. A histologic demonstration of siliceous materials in simian lung mite infected lung tissues by microincineration. Journal of Veterinary Science, v. 4, n. 2, p. 117-123, 2003.

KNEZEVICH, A.L.; MCNULTY, W.P. Pulmonary acariasis (Pneumonyssus simicola) in colony-bred Macaca mulatta. Laboratory Animal Care, v. 20, n. 4, p. 693-696, 1970.

LEATHERS, C. W. Pulmonary acariasis in an infant, colonyborn rhesus monkey (Macaca mulatta). Laboratory Animal Science, v. 28, n. 1, p. 102-103, 1978.

POVAR, M.L. Lung mites (Pneumonyssus simicola) in the feces of Macaca mulatta. Laboratory Primate Newsletter, v. 4 , n. 3 , p. $4,1965$. 
RAWLINGS, C.A.; SPLITTER, G.A. Pneumothorax associated with lung mite lesions in a rhesus monkey. Laboratory Animal Science, v. 23, n. 2, p. 259-261, 1973.

SILVERMAN, S.; POULOS, P.W.; SUTER, P.F. Cavitary pulmonary lesions in animals. Journal of the American
Veterinary Radiological Society, v. 17, p. 134-146, 1976.

WOODARD, J.C. Acarous (Pneumonyssus simicola) arteritis in rhesus monkeys. Journal of the American Veterinary Medical Association, v. 153, n. 7, p. 905-909, 1968.

Received on May 24, 2007.

Accepted for publication on December 15, 2007. 